Editorial

\title{
Editorial to the Issue on Climate Governance and the Paris Agreement
}

\author{
Jon Hovi and Tora Skodvin * \\ Department of Political Science, University of Oslo, 0317 Oslo, Norway; E-Mails: jon.hovi@stv.uio.no (J.H.), \\ tora.skodvin@stv.uio.no (T.S.) \\ * Corresponding author
}

Submitted: 9 August 2016 | Published: 8 September 2016

\begin{abstract}
This thematic issue of Politics and Governance serves as a Festschrift in honor of Professor Dr. Philos. Arild Underdal on his $70^{\text {th }}$ birthday. In this editorial, the guest editors summarize a few of Professor Underdal's many academic merits and achievements. They also provide a synopsis of each of the ten contributions to the Festschrift, which focuses on climate governance in general and the 2015 Paris Agreement in particular.
\end{abstract}

\section{Keywords}

Arild Underdal; climate governance; Festschrift; the Paris Agreement

\section{Issue}

This editorial is part of the issue "Climate Governance and the Paris Agreement", edited by Jon Hovi and Tora Skodvin (University of Oslo, Norway).

(C) 2016 by the authors; licensee Cogitatio (Lisbon, Portugal). This article is licensed under a Creative Commons Attribution 4.0 International License (CC BY).

Professor Dr. Philos. Arild Underdal is a remarkable academic. Not only is he an excellent political science scholar, he is also a very skillful administrator. In addition, Arild is a cherished teacher, supervisor, colleague, and collaborating partner. He has contributed to the recruitment of a number of skilled master and $\mathrm{PhD}$ students, included them in his wide academic network, inspired them to embark on an academic career, and thus still plays a major role in the continuous development of the IR and climate-change social-science research communities in the Oslo area. This thematic issue of Politics and Governance is a Festschrift to our friend and colleague, Arild Underdal, to honor him on his $70^{\text {th }}$ birthday.

Based in the Oslo region, Arild has had an astonishing career both as a scholar and administrator. He was awarded his doctoral degree in 1982 and became a full professor at the Department of Political Science, University of Oslo, in 1988. He has also been affiliated with other institutions in the Oslo region, including the $\mathrm{Bl}$ Norwegian Business School, the Fridtjof Nansen Institute (FNI), and the Centre for International Climate and Environmental Research-Oslo (CICERO). At all of these institutions, Arild has inspired and greatly influenced a large number of younger colleagues, including the guest editors and several other contributors to this volume. He has done so through his excellent teaching and supervision, as well as through his widely cited scholarly work. Some of this scholarly work has been co-authored with younger Oslo-based colleagues, with internationally renowned scholars from Arild's impressive international network, or-on occasion-both. Several of these internationally renowned scholars are also contributors to this volume and many others have served as anonymous reviewers.

Arild's administrative skills were acknowledged when he first served as prorector (1993-1995) and then as rector (2002-2006) of the University of Oslo (UiO). Many other academic institutions in Norway and abroad have sought his advice, as has also the Norwegian government. In 2006, he was awarded the highranking distinction of Commander of the Royal Order of St. Olav.

Important instruments for developing Arild's scholarly network domestically and internationally have been a set of large-scale research projects, often 
funded by the Research Council of Norway. The most recent-and one of the most important-of these projects has been Strategic Challenges in International Climate and Energy Policy (CICEP), a centre for environmentally friendly energy. This centre is located at CICERO, while the FNI and the Department of Political Science, UiO, serve as research partners. Arild lead the application process and also served as CICEP's director for the first two and a half years of its existence.

Cooperating with Arild is very inspiring and enjoyable; however, it is also slightly depressing. It is enjoyable because of his modest, friendly and patient appearance, because he invariably delivers top-quality work, and because he is always careful to keep deadlines. It is slightly depressing because no matter how hard you work, he works even harder. The following anecdote may illustrate the point. During his period as rector at UiO, the local student newspaper, Universitas, asked him to give an interview. To avoid wasting time, Arild requested that the interview be conducted while he had breakfast. Having granted Arild's wish, the journalist was astonished to learn that Arild had breakfast at $4 \mathrm{am}$ ! The interview reveals that a typical work day for Arild lasts 12 to 15 hours-including Saturdays and Sundays. Between Christmas and New Year's Eve he works only 10-12 hours a day, which Arild characterizes as "pure relaxation". ${ }^{1}$

During the last couple of decades, climate change has been a major area of research for Arild. Therefore, a natural focus of this Festschrift is climate governance in general and the 2015 Paris climate change agreement in particular. The festschrift includes 10 contributions.

Norway's lead climate negotiator Aslak Brun (2016) provides an insider's account of the Paris negotiations and the resulting agreement. He argues that the shift from a top-down to a bottom-up approach has helped spur participation, that the Paris agreement has established a new and clearer "direction of travel", and that its provisions may be expected to generate increased national mitigation efforts over time.

Oran R. Young (2016) considers whether the Paris Agreement is "destined to succeed or doomed to fail". He argues that to avoid dangerous climate change, major emitters such as China, the United States, the European Union, and India will have to deepen their current emissions reduction or limitation pledges by 2030 at the latest. Moreover, other important countries such as Brazil, Indonesia, Japan, and Russia must avoid taking action that would aggravate the problem. Without making a firm prediction, Young discusses whether fulfilling these two conditions might be feasible.

David Victor (2016) reviews what scholars and practitioners working on climate change cooperation have

${ }^{1}$ See http://universitas.no/magasin/5437/morgenstund-med-rektor learnt as their efforts have co-evolved over the past two decades. He finds that until Paris, very few lessons offered by scholars have had much influence on climate change negotiations. Moreover, cooperation theory and insights from case studies largely explain why those two decades achieved little progress. However, he also finds that the Paris agreement much better reflects insights from scholars about how to build effective international environmental institutions. He concludes that there is nevertheless no guarantee that Paris will eventually prove successful.

Robert 0 . Keohane and Michael Oppenheimer (2016) offer a preliminary assessment of the achievements of the Paris negotiations and of the conditions under which the Paris Agreement might generate policies and actions that can significantly influence global climate change. Having carefully reviewed the pledge and review system instituted at Paris, the authors analyze post-Paris climate politics as a strategic game. They conclude that the Paris Agreement merely creates an opening for effective action on climate change. To make Paris work, political action by domestic and transnational organized groups and a willingness to pay the economic price are required.

Thomas Bernauer, Liang Dong, Liam Francis McGrath, Irina Shaymerdenova and Haibin Zhang (2016) consider the prospects for deep emissions reductions in China-the world's biggest emitter of greenhouse gases-based on the Paris agreement's internationally coordinated and monitored unilateralism. In particular, they examine how Chinese citizens view the shift in climate policy from the reciprocal approach characteristic of Kyoto to the unilateralist approach inherent in Paris. Based on a survey experiment, the authors find forceful and robust public support for unilateral and non-reciprocal Chinese climate policy. Thus, their results suggest that China's government can rely on solid public support should it want to move forward with ambitious (i.e., costly) emissions reductions.

Detlef Sprinz, Bruce Bueno de Mesquita, Steffen Kallbekken, Frans Stokman, Håkon Sælen, and Robert Thomson (2016) report and compare three different attempts at predicting the outcome of the Paris negotiations. All of these three predictions were published several weeks ahead of the Paris meeting. One prediction was based on expert assessments, whereas the other two were based on two different formal models. The results show that the experts-on averageperformed somewhat better than the formal models did. However, the results also suggest that "combining experts' predictions to reach a collective expert prediction makes for significantly more accurate predictions than individual experts' predictions". The authors find no significant difference between the predictive accuracy of the two formal models.

Steinar Andresen, Torbjørg Jevnaker, Jon Birger Skjærseth, and Jørgen Wettestad (2016) analyze the 
Paris agreement's potential effects on the European Union and on international carbon markets, paying particular attention to the EU emissions trading system (EU ETS). Concerning the EU, the authors argue that Paris might-through various political, legal and bureaucratic-administrative pathways-increase pressure on current EU laggards. Regarding the EU ETS, they conclude that Paris might help further tighten this system and boost the carbon price; however, they add that it will likely be challenging to use the Paris Agreement in such internal processes.

Dag Harald Claes and Helge Hveem (2016) consider the likely effect of the Paris agreement on the global oil system. They maintain that the relevant causal chain is long and subject to several intervening factors. Therefore, the effect that Paris will have on oil is extremely difficult to predict. Discussing several factors that might influence the outcome, the authors argue that some of these factors are likely to support the Paris agreement. In contrast, other factors will likely have a neutral effect or may even work against it. They also present various scenarios for how Paris might influence different parts of the global oil system.

Guri Bang, Jon Hovi, and Tora Skodvin (2016) assess the potential effectiveness of Paris in the short and the long term. Concerning short-term effectiveness, they contend that while Paris scores high on participation and reasonably high on the depth of the parties' commitments, its Achilles' heel will likely be compliance. Concerning long-term effectiveness, they argue that Paris does little to restructure states' incentives so as to avoid free riding. However, depending on factors such as technological progress and major emitters' willingness to take the lead, domestic and international norms could continue to develop in a direction that makes it more and more difficult to ignore the plea to limit and reduce carbon footprints.

The Festschrift ends with a commentary by Miranda Schreurs (2016). She explores the domestic developments that led the EU, the United States and China to adopt the emissions reduction targets they agreed to in Paris and discusses whether a strengthening of these actors' climate action commitments can be expected in the coming period. She comments that while China may be best positioned to further strengthen its climate targets, the political situation in the EU and the U.S. will make it challenging, although not impossible, to strengthen their climate action commitments in the coming period. She cautions, moreover, that more ambitious climate commitments in the EU and the United States requires that climate skeptics are convinced of the benefits of early action.

\section{Acknowledgments}

We are grateful to Arild Underdal for everything he has done for us over the years, to the contributors to this Festschrift for accepting our invitation and conscientiously keeping the many (often tight) deadlines, to the many anonymous reviewers for their willingness to help out, to the editorial team of Politics and Governance for their cooperation, and to Rodrigo Gomes Quintas da Silva for his friendly and efficient handling of the entire process.

\section{Conflict of Interests}

The authors declare no conflict of interests.

\section{References}

Andresen, S., Jevnaker, T., Skjærseth, J. B., \& Wettestad, J. (2016). The Paris Agreement: Consequences for the EU and carbon markets? Politics and Governance, 4(3), 188-196.

Bang, G., Hovi, J., \& Skodvin, T. (2016). The Paris Agreement: Short-term and long-term effectiveness. Politics and Governance, 4(3), 209-218.

Bernauer, T., Dong, L., McGrath, L. F., Shaymerdenova, I., \& Zhang, H. (2016). Unilateral or reciprocal climate policy? Experimental evidence from China. Politics and Governance, 4(3), 152-171.

Brun, A. (2016). Conference diplomacy: The making of the Paris Agreement. Politics and Governance, 4(3), 115-123.

Claes, D. H., \& Hveem, H. (2016). From Paris to the end of oil. Politics and Governance, 4(3), 197-208.

Keohane, R. O., \& Oppenheimer, M. (2016). Paris: Beyond the climate dead end through pledge and review? Politics and Governance, 4(3), 142-151.

Schreurs, M. (2016). The Paris climate agreement and the three largest emitters: China, the United States, and the European Union. Politics and Governance, 4(3), 219-223.

Sprinz, D. F., Bueno de Mesquita, B., Kallbekken, S., Stokman, F., Sælen, H., \& Thomson, R. (2016). Predicting Paris: Multi-method approaches to forecast the outcomes of global climate negotiations. Politics and Governance, 4(3), 172-187.

Victor, D. (2016). What the Framework Convention on Climate Change teaches us about cooperation on climate change. Politics and Governance, 4(3), 133141.

Young, O. R. (2016). The Paris Agreement: Destined to succeed or doomed to fail? Politics and Governance, 4(3), 124-132. 


\section{About the Authors}

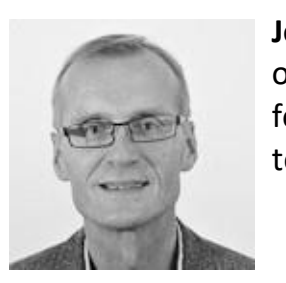

Jon Hovi is professor of political science at the University of Oslo. His research focuses on the design of international agreements, particularly the aspects pertaining to participation, compliance, and enforcement. Other research interests include the effectiveness of economic sanctions as well as strategic aspects of international and domestic armed conflict.

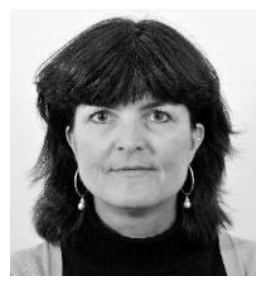

Tora Skodvin is professor of political science at the University of Oslo. Her main areas of interest include international negotiation with a particular focus on the international negotiations of climate change, the role of non-state actors in international climate policies and the domestic-international interface of U.S. and EU climate and energy policies. 